\author{
Danuta Drywa \\ Muzeum Stutthof w Sztutowie \\ danuta.drywa@stutthof.org
}

\title{
„Nasz mały sabotaż..." - rola polskich więźniarek w życiu obozowym (legalnym i nielegalnym) KL Stutthof
}

\author{
“Our Little Sabotage..." - The Role of Polish Women Inmates in the (Legal and \\ Illegal) Life of KL Stutthof
}

Abstract: Among the relatively small group of women who had been evidenced in the KL Stutthof by the end of 1943 there were Polish women inmates who, as far as it was possible, though not being able to help all the inmates, organized the so-called minor sabotage. It involved damaging German uniforms that had been sent in to be mended, burning in stoves the best furs cut up into small pieces, conveying illegally obtained radio information about the army front, organizing additional clothes and food for imprisoned men, damaging the best leather belts, cufflinks and clips to be packed with soldier outfits, as well as taking care of children and teenage inmates of the camp. Teachers and girl-scout activists organized for their fellow-women inmates poetry readings, religious festivals and - in 1944 - secret schooling. The women took advantage of every possible moment and opportunity to devote themselves to illegal work, however little they could do, and even while working under the supervision of kapos or German overseers.

Keywords: KL Stutthof, Stutthof concentration camp, Zivilgefangenenlager Stutthof, women in KL Stutthof

Streszczenie: Wśród stosunkowo niewielkiej grupy kobiet, które zostały zewidencjonowane w KL Stutthof do końca 1943 roku znajdowały się więźniarki Polki, które w miarę swoich możliwości organizowały tak zwany mały sabotaż. Polegał on na niszczeniu przywożonych do naprawy niemieckich mundurów, paleniu w piecach najlepszych pociętych na małe kawałki futer, przekazywaniu zdobytych nielegalną drogą informacji radiowych z frontu, organizowaniu dla mężczyzn dodatkowej odzieży i jedzenia, niszczeniu najlepszych pasków skórzanych i spinek pakowanych do różnych wyprawek żołnierskich, opiekowaniu się przebywającymi w obozie dziećmi i więźniami małoletnimi. Znajdujące się wśród nich nauczycielki i działaczki harcerskie urządzały dla współtowarzyszek niewoli wieczorki poetyczne, święta religijne, a w 1944 roku również tajne nauczanie. Kobiety wykorzystywały każdą nadarzającą się sposobność do nielegalnej działalności, choćby wydawało się, że niewiele mogą zrobić, nawet podczas wykonywania pracy pod nadzorem kapo czy niemieckich nadzorczyń.

Słowa kluczowe: KL Stutthof, obóz koncentracyjny Stutthof, Zivilgefangenenlager Stutthof, kobiety w KL Stutthof 
Funkcjonujący od 2 września 1939 roku obóz dla jeńców cywilnych (Zivilgefangenenlager Stutthof), a od 7 stycznia 1942 roku jako obóz koncentracyjny Stutthof (Konzentrationslager Stutthof), początkowo przeznaczony był wyłącznie dla mężczyzn Polaków, głównie przedstawicieli polskiej inteligencji oraz działaczy organizacji patriotycznych, aresztowanych na podstawie list proskrypcyjnych (Sonderfahndungsbuch), na całym Pomorzu Gdańskim od września 1939 roku do wiosny 1940 roku¹. Pierwsze kobiety więźniarki zostały odnotowane w aktach obozu Stutthof w 1940 roku. Chociaż, jak podają świadkowie tych wydarzeń, 1 września 1939 roku aresztowania w Gdańsku objęły niekiedy całe rodziny, które umieszczono w więzieniu Viktoria-Schule. Jednak około 50 kobiet wraz z dziećmi tego samego dnia po południu zwolniono, a zatrzymano jedynie te, których nazwiska znajdowały się na listach proskrypcyjnych ${ }^{2}$. Kolejne aresztowania kobiet na Pomorzu Gdańskim przeprowadzono wiosną 1940 roku. Od jesieni 1939 aż do wiosny 1940 roku na terenie całego Pomorza działały Komisje Rasowe (Rassenkomission), które orzekały o losach Polaków i ich rodzin. Wobec niektórych osób zapadały decyzje o wysiedleniu do Generalnego Gubernatorstwa, pewną grupę zatrzymano i następnie w kwietniu 1940 roku skierowano do obozu koncentracyjnego dla kobiet Ravensbrück, natomiast część rodzin wysłano do obozu przesiedleńczego w Prabutach (Übergangslager Riesenburg Westpreussen) ${ }^{3}$.

Pierwsza więźniarka została osadzona w obozie Stutthof w czerwcu 1940 roku, a do końca tego roku zarejestrowano jeszcze około 20 kobiet. W 1941 roku przeszło przez obóz około 300 kobiet. Były wśród nich między innymi działaczki Komendy Obrońcy Polski (KOP) z Pomorza, a od końca lipca 1941 roku za przewinienia popełnione w miejscu pracy do obozu zaczęto przysyłać więźniarki tak zwane wychowawcze (Erzehiegung), mimo że oficjalnie obóz Stutthof funkcję obozu pracy wychowawczej (Arbeitserziehungslager) pełnił od 1 października 1941 roku$^{4}$. Więźniarki te po odbyciu wymierzonej kary, trwającej najczęściej do 56 dni, były z obozu zwalniane z nakazem stawienia się do wyznaczonego urzędu pracy (Arbeitsamt). Więźniarki „wychowawcze” przybywają do obozu przez cały 1942 rok. Oprócz Polek odnotowywane są również Rosjanki i Ukrainki. Dopiero pod koniec 1942 roku, 1, 2 i 3 grudnia, w aktach KL Stutthof zarejestrowano

1 D. Drywa, Säuberungsaktion na Pomorzu Gdańskim w świetle dokumentów KL Stutthof (1939-1942), Sztutowo 2014, s. 33-48.

2 Relacja Jana Schoennagla [w:] B. Zwarra, Gdańsk 1939. Wspomnienia Polaków-Gdańszczan, Gdańsk 1984, s. 431; G. Danielewicz, M. Koprowska, M. Walicka, Polki w Wolnym Mieście Gdańsku, Gdańsk 1985, s. 87.

${ }^{3}$ Relacja Marianny Schwotzerowej [w:] B. Zwarra, dz. cyt., s. 439-440.

${ }^{4}$ Księga ewidencyjna więźniów, Archiwum Muzeum Stutthof (dalej: AMS), sygn. I-IIE-6, s. 197-201; J. Grabowska, Martyrologia kobiet i dzieci [w:] Stutthof- hitlerowski obóz koncentracyjny, red. D. Steyer, Warszawa 1988, s. 130. 
29 więźniarek Polizeihäftlinge: były to pochodzące z Torunia, Bydgoszczy, Starogardu, Osieka, Gdyni działaczki różnych organizacji ruchu oporu - Armii Krajowej, Szarych Szeregów, TOW „Gryf Pomorski”. To one w przyszłości odegrają największą rolę w organizowaniu nielegalnego życia obozowego 5 .

W 1943 roku w aktach obozowych zarejestrowano 1358 kobiet - są wśród nich działaczki „Gryfa Pomorskiego”, „Polskiej Armii Powstania”, „Polska Żyje", ale również kobiety z Kaszub, aresztowane jako zakładniczki za synów czy braci, którzy uciekli z Wehrmachtu i ukrywali się w bunkrach w Borach Tucholskich . Pod koniec 1943 roku w KL Stutthof osadzono 7 Dunek, które przybyły 5 października z grupą 150 komunistów duńskich, a 26 listopada 142 polskie Żydówki z getta białostockiego 7 .

Do połowy 1944 roku kobiety w KL Stutthof stanowily stosunkowo niewielki procent wszystkich więźniów. Sytuacja uległa zmianie, kiedy to od 29 czerwca do KL Stutthof zaczynają przybywać kilkutysięczne transporty z więźniami żydowskimi, wśród których przeważały kobiety. Do końca 1944 roku w KL Stutthof osadzono łącznie około 49000 Żydów, z czego ok. 80\% były to Żydówki pochodzące z Węgier, Polski, Litwy, Łotwy, Estonii, Niemiec, Czech, Słowacji, Rumunii i z innych okupowanych przez Niemców państw europejskich ${ }^{8}$.

Pod koniec sierpnia i września 1944 roku do KL Stutthof przybyło 700 kobiet Polek, w tym 40 młodych łączniczek z AK, w transportach z ewakuowanej Warszawy9. W tym samym czasie osadzane są Łotyszki, Estonki, a 13 sierpnia 1944 roku, odnotowano w aktach w KL Stutthof 18 Norweżek, które znajdowały się wśród 60 więźniów norweskich, aresztowanych za dziatalność w ruchu oporu ${ }^{10}$.

Główną kobiecą siłę roboczą na terenie obozu stanowiły początkowo Polki i Rosjanki. Jak wynika z wykazu więźniarek przebywających w bloku I, w 1942 roku kobiety-więźniarki ,wychowawcze”, kierowane były do pracy w najcięższych komandach obozowych - komanda leśnego (Waldkommando), Cegielni (Ziegelei), gospodarstwa rolnego Żuławy (Werderhof) ${ }^{11}$. Pracowały również w obozowych biurach, w kuchni obozowej przy obieraniu ziemniaków, w pralni, w obozowym ogrodnictwie.

${ }^{5}$ Księga ewidencyjna więźniów, AMS, sygn. I-IIE-6, dz. cyt., s. 197-198; J. Grabowska, dz. cyt., s. 131.

${ }^{6}$ Tamże; D. Drywa, Polacy z III grupy DVL osadzeni w KL Stutthof za ucieczki z Wehrmachtu [w:] Pomorzanie $w$ Wehrmachcie. Materiaty z XXI sesji naukowej $w$ Toruniu $w$ dniu 3 listopada 2011 roku, red. J. Sziling, Toruń 2012, s. 69-81.

7 J. Grabowska, dz. cyt., s. 132.

8 D. Drywa, Zagtada Żydów w obozie koncentracyjnym Stutthof (wrzesień 1939-maj 1945), Gdańsk 2001.

${ }^{9}$ Listy transportowe więźniów przestanych przez Sipo Warschau 31.08.1944 r. i 29.09.1944 r., AMS, sygn. I-IIB-7.

10 Lista transportowa więźniów, AMS, sygn. I-IIB-12; Księga ewidencyjna więźniów KL Stutthof, AMS, sygn. I-IIE-12, s. 234-240.

${ }^{11}$ Wykaz przeniesień na bloku nr I od 14.07.1942 r. do 26.03.1943 r., AMS, sygn. I-IIIB-1. 
W KL Stutthof wyróżniały się Polki osadzone w obozie w grudniu 1942 roku. Były to więźniarki, które, jak pisze Elżbieta Marcinkowska-Szuca, narzuciły w obozie postawę aktywności i wzajemnego poparcia:

Zaczęto się z nami liczyć. Tak samo było u mężczyzn. Tworzyłyśmy zwartą grupę i nieraz blokowa była zła, ale musiała uznać nasze postępowanie. Uczyłyśmy współżycia i udzielania pomocy ${ }^{12}$.

Panującą w tej grupie więźniów solidarność, zarówno kobiet, jak i mężczyzn, potwierdza Czesław Szlachcikowski:

Polizeihäftlindzy swoją postawą udowodnili, że w tym piekle, które w Stutthofie SS-mani stworzyli więźniom, w zwartej i zdyscyplinowanej grupie można sobie jakoś życie ułożyć. Wprowadziliśmy solidarność: jeden za wszystkich, wszyscy za jednego. Jeden drugiemu dawał rady ${ }^{13}$.

Zachowanie takiej postawy było ważne, gdyż początkowo więźniowie tej kategorii zostali odseparowani od pozostałych więźniów w obozie i mogli liczyć tylko na siebie:

Polizeihäftling był więźniem do dyspozycji Gestapo. Ponieważ nie było miejsca w więzieniu w Gestapo, odtransportowano nas do Stutthofu i tam wydzielono nas od reszty więźniów, odizolowano nas od nich. Chodziło o to, żebyśmy nie mieli kontaktu z innymi więźniami, bo nadal w Stutthofie przebywaliśmy jakby w śledztwie. Nasze sprawy w Gestapo nie zostały jeszcze zakończone i w każdej chwili każdy z nas mógł być wezwany na śledztwo do Gestapo. Dopóki śledztwo nie zostało zakończone, więzień nosił nazwę Polizeihäftlinga ${ }^{14}$.

Najczęściej wymienianymi więźniarkami oznaczonymi jako Polizeihäftlinge, które udzielały się w „legalnym” i „nielegalnym” obozowym życiu, są: Halina Strzelecka, Jadwiga Rotecka, Zofia Kopeć, Waleria Felchnerowska, lekarka Anna Paszkowska, obozowa poetka Lilka Banasiak, Helena Chrzanowska, Helena Gwiazda, Helena Jarocka, Ludwika Stenzel, Elżbieta Marcinkowska. Należy tu zaznaczyć, że była to pierwsza większa zorganizowana grupa więźniarek KL Stutthof, mająca w obozie pewne zaplecze. Zarówno ze względu na status „więźnia policyjnego" (więźnia w pewnym stopniu pozostającego poza władzą obozowa), jak i osadzenie w obozie w tym samym czasie innych działaczy organizacji ruchu oporu więźniarki mogły zawsze liczyć na czyjąś pomoc. Dzięki temu miały też większe możliwości podejmowania nielegalnej

12 Relacja E. Marcinkowskiej-Szucy, AMS, Relacje i wspomnienia, t. 6, s. 65

${ }_{13}$ Relacja Cz. Szlachcikowskiego, AMS, Relacje i wspomnienia, t. 6, s. 219.

14 Tamże, s. 217. 
aktywności w obozie. Więźniarki „wychowawcze”, które przebywały w obozie okresowo, pochodzące z różnych terenów Pomorza Gdańskiego, nieznające nikogo w lagrze, nie mogły stworzyć trwałych relacji z innymi i regularnie współpracować ze sobą w różnych zakresach życia obozowego. Jak wynika jednak z relacji Anny Paszkowskiej, także one włączały się w nielegalną działalność, gdyż wychodząc po odbyciu kary, przekazywały paczki i informacje od pozostających w obozie osób ich rodzinom ${ }^{15}$.

W obozie koncentracyjnym czasami trudno było całkowicie oddzielić działalność legalną od nielegalnej. Zarówno mężczyźni, jak i kobiety podczas wykonywania pracy pod nadzorem kapo czy niemieckich nadzorczyń wykorzystywały każdą nadarzającą się sposobność do nielegalnej działalności, nawet jeśli wydawałoby się, że miała ona niewielkie znaczenie. Jako karne przeniesienie traktowano skierowanie do komanda zewnętrznego, w którym pracowały głównie więźniarki rosyjskie. Była to praca na roli u okolicznych rolników niemieckich, trwająca od wiosny do jesieni, przy przerywaniu buraków cukrowych, później przy żniwach zbóż i rzepaku, zbiorze ziemniaków i buraków, przy młocce rzepaku. Jednak i tu nadarzały się okazje do uprawiania niewielkiego „sabotażu”. Więźniarki wychodzące z obozu do pracy w komandzie zewnętrznym miały możliwość spotykania się z polskimi robotnikami przymusowymi, pracującymi u niemieckich gospodarzy. Za ich pośrednictwem przekazywały listy od więźniarek, w których informowano o realiach życia obozowego. Przemycały ubrania robocze dla robotników, a w zamian otrzymywały cebulę, ziemniaki i chleb. Działalność niezgodna z regulaminem obozowym była możliwa tylko w sytuacji, gdy pilnujący więźniarek strażnik nie wykonywał gorliwie rozkazów władz obozowych. W grupie tej przez pewien okres pracowała Anna Paszkowska:

Każdego dnia wyjeżdżałyśmy rano wozem albo samochodem, albo kolejką - były różne środki lokomocji i w różne miejsca nas wożono. Więc u jednego bauera kopałyśmy ziemniaki, na żniwa chodziliśmy do innego - tak to było różnie i różne były odległości. Zasadniczo źle nie było. Zależało od tego, kto z nami szedł. Chodzili zwykle prości żołnierze. Bywali tacy, którzy pokazywali nam fotografie swoich żon, swoich dzieci, twierdzili, że do SS poszli tylko z przydziału, wcale sami nie chcieli tam być. Układali się w bruździe, tylko prosili, żeby pilnować jak nadejdzie jakaś kontrola, żeby ich w porę obudzić. Bywali tacy, ale bywali i inni. Pamiętam przy jakichś żniwach, to się odbywało w ten sposób, że myśmy podbierały i wiązały, a on jeździł maszyną konną. Ja ledwie mogłam nadążyć. Więc powiedział, że jak on jeszcze raz przyjedzie, a ja nie będę gotowa, to on nie będzie czekał tylko najedzie na mnie tymi końmi. Wyglądało tak, że on naprawdę może to zrobić. Więc wtedy wracałam do obozu bardzo wymęczona, podobno sina, bardzo wyczerpana, ale nawet lagier można było przetrzymać mając przyjaciół oddanych i życzliwych.

15 Relacja A. Paszkowskiej, AMS, Relacje i wspomnienia, t. 15, s. 134. 
Ja miałam całą grupę taką życzliwą, a przede wszystkim Halinę Strzelecką. Jak wracałam z Aussenkommando miałam zawsze gotową kolację ${ }^{16}$.

Sposób zdobywania dodatkowej odzieży, którą więźniarki zaopatrywały spotkanych na pracach rolnych polskich robotników przymusowych oraz współwięźniów, przedstawiła Elżbieta Marcinkowska-Szuca:

Na Flickkamerze kapową była Maria Wittowa, a ona nigdy nie odmówiła. Tam się zamawiało np. koszulę. Nazywało się to organizowaniem. Koszule oddawało się potem do pralni i pani Stefaniakowa, która teraz pracowała, prasowała te koszule. Przekazywało się bieliznę za pośrednictwem kobiet pracujących na nowym obozie, ponieważ one w czasie pracy kontaktowały się z mężczyznami. Poza tym mężczyźni przyjeżdżali wozem pod pralnię na naszym obozie po odbiór bielizny i wtedy dawało się im bieliznę przeznaczoną dla naszych mężów czy braci ${ }^{17}$.

Pod koniec 1943 roku kobiety zostały zatrudnione w warsztatach powstałych przy DAW - w warsztacie kuśnierskim (Kürschnerei, nazywanym też Peltzkammer), szewsko-siodlarskim (Schumacherei-Sattlerei), krawieckim (Schneiderei) ${ }^{18}$. Pracując $\mathrm{w}$ warsztacie kuśnierskim, więźniarki najlepsze futra przeznaczone dla wojska cięły na małe kawałki, którymi paliły w piecu, jak pisze Helena Jarocka: „(...) zadowolone, że chociaż w ten sposób możemy posabotować":

Ja dostałam się do Peltzkammer. Szyłyśmy tam futra dla lotników żołnierzy niemieckich na Wschodzie. Pracowałam tam m. in. z panią Chrzanowską. Uprawiałyśmy tam sabotaż; lepszą skórę cięłyśmy na kawałki i paliłyśmy w piecu, a z gorszej szyłyśmy futra. Nie zauważano tego, bo w warsztacie i tak pełno było obrzynków futer. Rosjanki nauczyły nas lepszej formy sabotażu. Wyznaczono nam normę zdaje się zrobienia 10 futer dziennie. Rosjanki, które cierpiały w obozie wielki głód, dawały nam już gotowe, uszyte futra w zamian za chleb. Dziwiłyśmy się, że one potrafią tak dużo futer uszyć, tymczasem okazało się, że one wyciągały gotowe futra z magazynów i te właśnie futra dawały nam za chleb. Nauczone przez Rosjanki zaczęłyśmy robić tak samo. Esesmani nie wykryli tego sabotażu. Wydawało się im, że to niektórzy z nich okradają magazyny ${ }^{19}$.

16 Tamże, s. 131-132.

17 Relacja E. Marcinkowskiej-Szucy, dz. cyt., s. 65.

18 M. Orski, Niewolnicza praca więźniów obozu koncentracyjnego Stutthof w latach 19391945, Gdańsk 1999, s. 146.

${ }_{19}$ Relacja H. Jarockiej, AMS, Relacje i wspomnienia, t. 9, s. 53; tejże, t. 18, s. 93. 
Za swój mały sabotaż więźniarki uważały również niszczenie najlepszych żołnierskich pasków skórzanych i spinek pakowanych do wyprawek wojskowych czy sposób, w jaki rozdzielały szelki. Te w najlepszym stanie przekazywały do męskiego obozu, te podniszczone paliły, piekąc na nich „zorganizowane” ziemniaki, a te najgorsze pakowały dla niemieckich żołnierzy ${ }^{20}$.

Kobiety pracujące $\mathrm{w}$ warsztacie szewsko-siodlarskim zorganizowały nieoficjalną pocztę przenoszoną w worku, w którym dostarczano kobietom wzory do pracy. Inicjatorem tej poczty był kapo Mieczysław Goncarzewicz, nadzorujący pracę męskiego i żeńskiego warsztatu szewsko-siodlarskiego. W ten sposób więźniarki przekazywały dla mężczyzn, wśród których nierzadko byli ich mężowie lub synowie, bieliznę, swetry, żywność i listy. Drogą zwrotną otrzymywały papierosy i listy, które przekazywały innym kobietom ${ }^{21}$.

O panującej w warsztacie krawieckim atmosferze pisze Maria Klosek-Reiter, która w KL Stutthof została osadzona w lipcu 1943 roku za działalność w organizacji TOW „Gryf Pomorski”:

W Schneiderei miałyśmy kontakt z mężczyznami, którzy również pracowali w tych warsztatach. Mężczyźni przynosili nam mundury do naprawy, a w tych przynoszonych przez nich mundurach znajdowały się listy, wiadomości polityczne o wydarzeniach w Polsce i na całym świecie, wiadomości lokalne z biura politycznego, wiadomości osobiste. My, idąc do pracy w Schneiderei, przenosiłyśmy skarpety, rękawiczki, które dostawałyśmy w Flickkammer, a także wiadomości. Te wszystkie rzeczy wkładałyśmy w wyreperowane przez nas mundury, które znowu mężczyźni od nas zabierali. Były to sprawy bardzo ważne, bo pomagały przetrwać w obozie ${ }^{22}$.

W akcjach współpracy i niesienia pomocy współwięźniom wyróżniała się Helena Jarocka, o której Anna Paszkowska napisała:

Jarocka była czymś w rodzaju pomocnicy - takiej sekretarki. Myśmy razem prowadziły ewidencję normy dziennej, odstaw. (...) Ona żyła ciągle końcem wojny, miała ciągle jakieś sny, widzenia, jakieś zapowiadania. Miałyśmy taki kalendarzyk - na nim stale powtarzało się „KW” - to był koniec wojny. Jak minęło jedno KW, to znów w następnym miesiącu znajdowało się jakieś KW. To ją trzymało, poza tym miała męża, o którym nic nie wiedziała, a który był bardzo mocno w akcji i trzy córki, do których ciągle wysyłała paczki przez odchodzące arbeitschoierki [Arbeitsscheu-więźniarki wychowawcze osadzone w obozie za „lenistwo" w czasie pracy - D.D.] i ciągle szyła ubranka dla lalek swych córek. Były to fantastyczne paczuszki - ubrania dla lalek do szkoły, spacerowe. To ją trzymało. Poza tym była to niesłychanie dzielna osoba, jeśli chodzi o pomoc

20 Relacja H. Jarockiej, dz. cyt., t. 18, s. 100.

${ }^{21}$ Tamże, s. 94; Relacja A. Paszkowskiej, dz. cyt., s. 133; M. Orski, dz. cyt., s. 146.

${ }^{22}$ Relacja M. Klosek-Reiter, AMS, Relacje i wspomnienia, t. 6, s. 29-30. 
mężczyznom. I to tak bez wyboru. Ją zupełnie nie obchodziło, czy podaje znajomemu czy nieznajomemu. To samo było w pralni i to samo było później. Zupełnie nie kierowała się jakimiś względami znajomości, tylko pomagała pierwszemu lepszemu, który się nawiną ${ }^{23}$.

Ze względu na początkowe odizolowanie więźniów - Polizeihäftinge od pozostałych więźniów w obozie, więźniów funkcyjnych - kapo i blokowych - wybierano spośród własnego grona. Jak pisze Czesław Szlachcikowski, ta izolacja i stworzony w ten sposób podział wśród samych więźniów nie był przypadkowy:

Władze esesmańskie w obozie specjalnie stworzyły rozdział pomiędzy polizeiheftlingami a resztą więźniów. Esesmani wmawiali więźniom, że jesteśmy przestępcami, bandytami, ludźmi niebezpiecznymi i dlatego nie wolno się z nami kontaktować. Więźniowie byli zdezorientowani, nie wiedzieli, kim właściwie jesteśmy. Izolacja polegała m.in. na tym, że chodziliśmy do pracy w oddzielnych grupach. Ja np. pracowałem $\mathrm{w}$ waldkolonie. Oprócz nas pracowały tam inne grupy więźniów, ale my stanowiliśmy zupełnie odrębną grupę, mieliśmy swoich kapów, swoich blokowych. Po apelu polizeiheftlindzy wychodzili zwartą grupą do swojego bloku, podczas gdy innym więźniom wolno było mieszać się z sobą, nam nie wolno było tego robić24

Jako kapo kobiecego oddziału warsztatu szewskiego wybrana została doktor Anna Paszkowska, a kapo warsztatu krawieckiego Ludwika Stenzel ${ }^{25}$. O postawie może świadczyć ich zachowanie, kiedy wykryto, zakazane dla kobiet, palenie papierosów na sztubie w baraku kobiecym. Przeprowadzono wówczas śledztwo:

Blokowa od razu wpadła na trop. Jedyna droga to DAW. Odpowiadają obie arbeitskapo Hanka Paszkowska i Lutka Stenzel. Chemnitz, Rappotführer, wziął je na przesłuchanie. Dwa dni stały, podczas posiłku, głodne na zewnątrz bloku z nosem przy ścianie. Nie zdradziły ${ }^{26}$.

O panujących stosunkach między kapo a pracującymi więźniarkami w kobiecym warsztacie krawieckim wspomina Maria Klosek-Reiter:

Komando Schneiderei prowadziła pani Ludwika Stenzel, przy pomocy pani Haliny Strzeleckiej. W Schneiderei pracowało prawdopodobnie 50 kobiet. Cerowałyśmy tam, reperowałyśmy uniformy wojskowe. Początkowo były zwykłe maszyny, później elektryczne. Pani Bronisława Stenzel wprowadziła tam atmosferę

23 Relacja A. Paszkowskiej, dz. cyt., s. 134.

${ }^{24}$ Relacja Cz. Szlachcikowskiego, dz. cyt., s. 218.

${ }_{5}$ M. Orski, dz. cyt., s. 147.

${ }^{26}$ Relacja H. Jarockiej, dz. cyt., t. 18, s. 95. 
wzajemnej życzliwości, miała duże poczucie humoru. Śpiewało się tam w czasie pracy polskie piosenki ludowe, narodowe, kościelne, oczywiście już po przeglądzie wachmanów. A w niedzielę w czasie pracy czytałyśmy, modliłyśmy się. Urządzałyśmy też w niedzielę w Schneiderei msze niedzielne. W Schneiderei robót doglądał majster, jakiś Niemiec, który pozwalał nam modlić się. W czasie naszych modlitw on wychodził. To samo działo się na oddziale kuśnierskim²7.

Anna Paszkowska i Ludwika Stenzel zostały osadzone w obozie wraz z mężami. Mąż Anny Paszkowskiej, Jerzy Paszkowski, został zamordowany w obozie już 4 grudnia 1942 roku $^{28}$. Za upomnienie się o rękawice potrzebne do pracy uderzony został przez esesmana kolbą w ciemię. Wywleczony w gorączce przez kapo w nocy na mróz, skonał pod barakiem. Żona musiała wystawić mu orzeczenie o śmierci, a jako przyczynę zgonu wpisać „na serce”. W pewnym stopniu komendantura obozu obawiała się reakcji gestapo, gdyż mógł to być ważny dla śledztwa świadek, dlatego podana w tym przypadku oficjalna przyczyna śmierci nie mogła być efektem działalności obozowych oprawców ${ }^{29}$. Potwierdza to jeden z więźniów, Czesław Szlachcikowski:

Traktowano nas trochę inaczej niż innych więźniów w obozie. Po prostu żaden $z$ nas nie mógł zginąć zanim w Gestapo nie zakończono śledztwa. I tak np. Hoelzer słynął w obozie z okrucieństwa. Ale u nas, jeżeli bił któregoś z więźniów za jakieś drobne przewinienie i jeżeli to bicie zaczynało zagrażać życiu więźnia, Selonka przerywał bicie. Bito nas tak jak i pozostałych więźniów, ale do pewnych granic. Bicie nie mogło się skończyć śmiercią więźnia ${ }^{30}$.

Kobiety pracujące w warsztacie krawieckim poza oficjalną pracą wykonywały z wełny pozyskiwanej ze sprutych swetrów skarpety i nauszniki dla mężczyzn, a więźniarki, które pozostawiły na wolności dzieci, sporządzały z resztek skór, futer, zabawki dla dzieci i drobne przedmioty codziennego użytku dla siebie i innych ${ }^{31}$.

W styczniu 1943 roku więźniarka z grupy osadzonej 1 grudnia 1942 roku, Cecylia Ciesielska, z polecenia władz obozowych zorganizowała warsztat wyrobów ze słomy, Strohschuhmacherstube (Strohstube), nad którym fachową opiekę pełnił Mieczysław Goncarzewicz ${ }^{32}$.

${ }^{27}$ Relacja M. Klosek-Reiter, dz. cyt., s. 28-29.

${ }^{28}$ Księga zgonów USC, AMS, sygn. Z-V-8.

29 Tamże, s. 76; Relacja A. Paszkowskiej, dz. cyt., s. 128-129.

${ }^{30}$ Relacja Cz. Szlachcikowskiego, dz. cyt., s. 218-219.

${ }^{31}$ Relacja H. Jarockiej, dz. cyt., t. 18, s. 96, 100.

${ }^{32}$ M. Orski, dz. cyt., s. 149. 
Pewnego dnia na apelu wywołano moje nazwisko. Z przerażenia nogi pode mną się ugięły, ponieważ przypuszczałam, że spotka mnie coś najgorszego. Kazano mi zgłosić się w Politische Abteilung [Wydział Polityczny - D.D.]. Okazało się, że komendantura w porozumieniu z Gestapo postanowiła na terenie obozu otworzyć Strohschuhstube. W Berlinie była taka pracownia bucików ze słomy, więc chciano też i w Stutthofie coś podobnego utworzyć. Ponieważ z moich dokumentów wynikało, że jestem nauczycielką ze specjalizacją prac ręcznych, polecono mi zorganizowanie tej pracowni i wytypowano na kapo. Zgodziłam się na to zadowolona, że będę pracować pod dachem. Powiedziałam, że owszem, ale muszę dostać jeden egzemplarz takich bucików żeby zobaczyć jak one wyglądają. Dostarczono mi jedną parę. Powiedziałam wtedy, że będę potrzebowała słomę, materiał, nici, tekturę i inne rzeczy, ale sama tego nie mogę robić, bo jeżeli to ma być masówka, to muszę mieć do dyspozycji więcej osób. Władze zgodziły się, więc ja, korzystając z okazji, wszystkie panie, które były z naszej grupy, wciągnęłam do tej pracy. Pracę podzieliłam. Jedna grupa $\mathrm{z}$ koleżanką Gwiazdową na czele przebierała słomę. Druga ją moczyła, a trzecia plotła warkoczyki ze słomy. W pracy tej doszły do perfekcji siostry Dąbrowskie - Jadzia, Henia i Lodzia oraz Teresa, której nazwiska nie pamiętam. Inna grupa szyła zelówki - z Kazią Bartel i Jadzią Rotecką na czele. Wanda Sokolnicka robiła rysunki - modele, według których szyłyśmy wierzchy. Instrukcji fachowej udzielał nam kol. Goncarzewicz - szewc. Aufseherka Aufseherinnen, nadzorczyni SS Kopp ciągle nas dopingowała do wykonywania większej ilości bucików, lecz tłumaczyłam jej, że mamy zbyt ciasne pomieszczenie (pracę wykonywałyśmy na bloku w swojej izbie) i przede wszystkim trzeba by przydzielić nam izbę na warsztat i zatrudnić większą liczbę kobiet. Argumenty nasze uznano z czasem za słuszne i przydzielono nam jedną izbę na starym lagrze na pracownię. Mieściła się ona na przeciwko kuchni tak, że władze SS miały nas na oku, no i blokowa ${ }^{33}$.

Produktem ubocznym pracy wykonywanej w Strohschuhmacherstube były różnego rodzaju drobne przedmioty - pamiątki wykonywane dla własnego użytku, jak bransoletki, małe buciki, etui, a sam warsztat stał się miejscem, w którym potajemnie organizowano różne uroczystości. Było to możliwe dzięki panującej w warsztacie wzajemnej życzliwości i pomocy, o czym pisze Elżbieta Marcinkowska-Szuca:

Kopka [Anna Kopp - D.D.] przynosiła różne materiały, m. in. przyniosła kiedyś stułę. Nie zużyłyśmy jej jednak na buty. Tygodniowo Kopka odbierała ze Strohstuby kilka par tych butów. Były one bardzo ładne. Każda para była inna, miała inny wzór. Oprócz tego robiło się w Strohstubie różne drobiazgi, pamiątki dla siebie. Pracowałam tam do końca mojego pobytu w Stutthofie. Przez bardzo krótki czas pracowałam w Schneiderei na nowym obozie. W Strohstubie przy pracy

${ }^{33}$ Relacja C. Ciesielskiej, AMS, Relacje i wspomnienia, t. 15, s. 13-14. 
śpiewałyśmy piosenki, recytowałyśmy wiersze. Jadzia Połonówna zawsze obserwowała przez okno czy na lagrze jest „czyste powietrze”. (...) W Strohstubie byłyśmy bardzo zżyte. Była to odskocznia od grozy obozowej. Ponieważ Kopka i inne wachmanki rzadko zaglądały do Strohstuby, tam skupiało się nasze życie. Tam właśnie miałyśmy pierwszą szopkę, którą chowałyśmy za piecem. Kiedyś urządziłyśmy tam apel poległych. Urządzałyśmy też wieczorki, na których recytowało się wiersze, również humorystyczne. Gotowałyśmy tam nawet obiady. Duszą Strohstuby była Jadwiga Rotecka-Szewczykowa. Pięknie śpiewała i rozśpiewała wszystkich. Była bardzo pracowita i bardzo ofiarna. Umiała załatwić wszelkie zatargi z blokową. Blokowa Jackowska była bardzo złośliwa, szukała okazji, żeby nam dokuczyć. Szczególnie nienawidziła w naszej grupie Heli Jarockiej, Hanki Paszkowskiej i Haliny Strzeleckiej. Na stubie zawsze wieczorem śpiewałyśmy i odmawiałyśmy wieczorną modlitwę $e^{34}$.

Pracujące w warsztacie krawieckim więźniarki miały możliwość zdobywania i kolportowania zabronionych w obozie wieści z zagranicznych stacji radiowych. Dwie wybrane więźniarki, Agnieszka Recław i Zofia Kopeć, czytały prenumerowane w obozie niemieckie gazety i informacje w nich zawarte porównywały z wiadomościami uzyskiwanymi z radia. Sprzymierzeńcem, który umożliwiał słuchanie zagranicznych stacji radiowych, był niemiecki więzień, inżynier, pracujący w obozie jako mechanik, o imieniu Hans. Więźniarki sprzątające pokoje esesmanów, w porozumieniu z Hansem, zorganizowały akcję psucia odbiorników radiowych:

$\mathrm{Na}$ dane przez Hansa hasło umówiona sprzątaczka wykręcała sobie wiadomą śrubkę z aparatu i wręczała Hansowi (był łatwo uchwytny, bo biegał po lagrze, reperując różne maszyny). Esesman zanosił Hansowi niefunkcjonujący aparat następny do reperacji i Hans obiecał go zreperować jak najszybciej. Nocami, zamiast reperować, słuchał zakazanych stacji nadawczych i konotował wiadomości w pamięci, a pamięć miał świetną. Po kilku dniach wręczył esesmanowi radio z całą legendą opisującą trudności reperacji. W międzyczasie następny aparat w ten sam sposób zepsuto. I tak w kółko. U nas z kolei na umówione hasło nasza Kaszubka wykręcała wiadomą śrubkę z maszyny i wręczała ją mnie, a kapo Hanka składała meldunek o popsuciu się maszyny z prośbą o rychłą reperację. Na ten alarm przybywał Hans i żądał, żebym pomogła mu w reperacji, bo znałam niemiecki. W przeciągu godziny zdał mi obszerne sprawozdanie z wiadomości radiowych, następnie wkręcał śrubkę i poszedł. Wiadomości przekazywałam Zosi i Adze. Rozeznanie i wyciąganie wniosków należało do nich. No i tak szły te polityczne parole w lagier ${ }^{35}$.

\footnotetext{
${ }^{34}$ Relacja E. Marcinkowskiej-Szucy, dz. cyt., s. 64.

${ }^{35}$ Relacja H. Jarockiej, dz. cyt., t. 18, s. 96.
} 
Szczególną opieką kobiety otaczały obozowe dzieci. Pod koniec 1943 roku do KL Stutthof przywieziono grupę dzieci z Grodna. Zostały one umieszczone w pobliżu kobiecego warsztatu Strohstube. Pomimo że dostęp do nich był zabroniony, więźniarki zainicjowały akcję dożywiania dzieci i organizowania dodatkowej odzieży i bielizny:

Dostęp do bloku dziecięcego był zabroniony, tak więc Hela Chrzanowska wiele ryzykowała, odwiedzając codziennie dzieci choćby na chwilę. Hela zorganizowała dla dzieci dożywianie. Przez Halinę Strzelecką otrzymywała dla nich zulagi od więźniarek pracujących w DAW. Dla dzieci zbierała też żywność po izbach. Przemycała również zabawki dla dzieci - piłki, misie, lalki - sporządzone przez artystycznie uzdolnione więźniarki. Drewniane zabawki na ręce Helusi przesyłali więźniowie pracujący w stolarni. Helusia organizowała również dla tych dzieci bieliznę i odzież z magazynu odzieżowego. Dzieci spragnione macierzyńskiej pieszczoty garnęły się do Helusi. Między nimi był 11-letni chłopczyk imieniem Lońka, pełen temperamentu, którego ani głód, ani poniewierka nie potrafiły okiełznać. Helusia szczególnie nim się interesowała i wieczorami w sztubie opowiadała o dokonanych przez niego psotach. Któregoś dnia Lońka wysmarował wszystkie dzieci sadzami i trzeba było robić generalne mycie dzieci w ciepłej wodzie. O wodę postarała się Helusia w pralni. Lońka wymyślał też różne zabawy, do których wciągał wszystkie dzieci. Ulubioną jego zabawą było sporządzanie z odpadków (szmat, słomy, drewienek) bombowców i rzucanie ich na „szwabów”36.

W marcu 1944 roku dzieci te zostały wywiezione do dziecięcego obozu koncentracyjnego Tuchingen (Konstantynów pod Łodzią) ${ }^{37}$.

Inna więźniarka z tej grupy, Helena Gwiazda, podczas panującej w obozie epidemii tyfusu straciła jednego $\mathrm{z}$ dwóch synów przebywających razem z nią w obozie, Wojciecha ${ }^{38}$. Po jego śmierci codziennie podchodziła do ogrodzenia oddzielającego obóz męski od żeńskiego, chociaż było to zabronione. Jak pisze Helena Jarocka:

A ona tam stała i szeptała czułe, serdeczne słowa do kogoś zza drutów. Esesman spostrzegł kobietę przy owych drutach i podszedł, żeby jej nawymyślać i precz odgonić. Słyszał jej prędki nerwowy, serdeczny głos - lecz za drutami nie ujrzał nikogo. Zdziwił się i zapytał, co ona tam robi? Gwiaździna odpowiedziała łamaną niemczyzną, że przyszedł jej syn Wojtek i rozmawia z nim. (...) Esesman wiedział widocznie, że Gwiaździna straciła syna, bo przeraził się okropnie i uciekł.

36 Tamże, s. 92.

${ }^{37}$ Lista transportowa więźniów wywiezionych do KL Tuchingen 28.03.1944 r., AMS, sygn. I-IIC-3.

${ }^{38}$ Księga ewidencyjna więźniów, AMS, sygn. I-IIE-6. Helena Gwiazda wraz z synem Wojciechem zostali osadzeni w KL Stutthof 3.12.1942 roku, Maciej Gwiazda przybył do obozu 9.02.1943 roku, a Wojciech Gwiazda zmarł w obozie 26.04.1943 roku. 
A Gwiaździna późnymi wieczorami odtąd przez przeszkód podchodziła do zakazanych drutów i rozmawiała długie chwile ze swym zmarłym synem ${ }^{39}$.

Po śmierci jednego z synów Helena Gwiazda została przybraną matką młodocianych chłopców, wożących do obozu kobiecego kotły z jedzeniem. Zdobywała dla nich dodatkowy chleb, a z magazynu odzieżowego dodatkową garderobę - „wkładała w tę akcję tyle serca, że nikt jej nie odmawiał pomocy”"

W grupie więźniarek przybyłych do obozu w grudniu 1942 roku, było kilka nauczycielek: Waleria Felchnerowska, Halina Strzelecka, Helena Jarocka czy Elżbieta Marcinkowska, które przygotowywały wieczorki poetyckie, poświęcone różnym polskim wieszczom narodowym, a w 1944 roku zorganizowały w obozie tajne nauczanie. Helena Jarocka udzielała lekcji matematyki podczas pracy w warsztacie szewskim i wieczorami w sztubie:

Był między innymi wieczór reymontowski. Halina omówiła życiorys i działalność Reymonta. Czytano wyjątki ze zdobytego w Effektenkammer (magazyn rzeczy odbieranych więźniom) egzemplarza Chtopów. Pamiętam wyjątki, które sama czytałam. Był to sąd Bartka o kradzież wieprzka i wypasanie koni proboszcza na cudzych łąkach. Wyjątki pełne humoru, wyzwalające burze śmiechu. Był jeszcze jeden wieczór mickiewiczowski z Redutą Ordona i wyjątkami z Konrada Wallenroda oraz z Sonetami. Jeden sonet zaśpiewał chór. Z innych wieczorów pamiętam wieczór Krasickiego - deklamowano Bajki, które komentowała Halina Strzelecka. Na wieczorze Słowackiego deklamowano poezje narodowo-wyzwoleńcze. Odbył się również wieczór Konopnickiej z jej patriotycznymi wierszami i wieczór z wierszami Kasprowicza, Staffa i innych. Powyższe imprezy organizowała Halina. Była również inicjatorką tajnego nauczania i jako jednoosobowa komisja, w razie wpadki, całą odpowiedzialność brała na siebie. (...) Znała wiele wyjątków poezji na pamięć, przepisywała je i wręczała co zdolniejszym deklamatorkom (...). Od nowego roku 1944 Halina urządzała tajne nauczanie, które trwało przez cały rok. Indywidualnie zwracała się do nauczycielek, wtajemniczając je w całość akcji. Do mnie zwróciła się z prośbą o nauczanie matematyki. Podrzuciła mi kilka uczennic, z których pamiętam tylko Lodzię Dąbrowską. Opracowywałam z nią materiał szkoły średniej. Lekcje odbywały się w warsztacie szewskim, gdzie pracowałyśmy. Innym dziewczętom udzielałam lekcji i przerabiałam z nimi materiał z klasy VI i VII szkoły podstawowej. Nazwisk uczennic już nie pamiętam. Lekcje z nimi odbywały się wieczorami w sztubie. (...) Lekcje odbywały się bądź w kąciku w sztubie, bądź podczas spaceru po ulicy lagrowej. (...) Poza tym każda z nas, nauczających, starała się przy każdej okazji uczyć poprawnej wymowy ojczystego języka, rugając błędy gramatyczne i różne naleciałości ${ }^{41}$.

39 Relacja H. Jarockiej, dz. cyt., t. 18, s. 114.

${ }^{40}$ Tamże, s. 100-101.

${ }^{41}$ Tamże, s. 88-89. 
Halina Strzelecka udzielała lekcji języka polskiego i historii, podobnie Waleria Felchnerowska w zorganizowanym przez siebie kółku młodzieżowym. Ta ostatnia nazwana została przez więźniarki „proboszczem”, gdyż już w pierwszych dniach po przybyciu do obozu próbowała podnieść je na duchu, intonując wspólne odmawianie modlitw i śpiewy religijne ${ }^{42}$. Sama też z pamięci spisała modlitewniki, które służyły do odprawiania po kryjomu mszy św. Jak pisze Helena Jarocka:

Od czasu do czasu organizowałyśmy również późnymi wieczorami nabożeństwa religijne. Na głos gongu na ciszę nocną jeden z kapłanów z dala, z męskiego obozu udzielał nam absolutorium, a potem w skupieniu przyjmowałyśmy Komunię Św. i śpiewałyśmy religijne pieśni. Komunikanty przynosiła nam Zosia Buske, która pracowała w Neubau (budynku zamieszkałym przez władze lagrowe), jako sprzątaczka. Otrzymywała je od księdza, który również tam był zatrudniony. Same komunikanty pochodziły od Litwinów. O północy jeden z litewskich więźniów - ksiądz, odprawiał mszę. Wino i opłatki Litwini otrzymywali w paczkach Czerwonego Krzyża. Paczek ich, jako Ehrenhäftlingów (więźniów honorowych) nie rewidowano ${ }^{43}$.

Nauka języka polskiego, którego zakaz używania wprowadzono na Pomorzu, a także historii Polski, odprawianie mszy świętych nawet w warunkach obozu koncentracyjnego, miały zapewnić w przyszłości polską ciągłość kulturową Pomorza. Więźniarki pochodziły z Pomorza, gdzie ludność polska już od czasu pierwszego zaboru pruskiego zmagała się z germanizacją. Rozbudzona pod koniec XIX w. tożsamość narodowa, ugruntowywana i rozwijana przez różne polskie związki zawodowe i społeczne, które miały największy wpływ na kształtowanie postaw społeczeństwa polskiego tych ziem, była odpowiedzią na ekspansywne żądania niemieckie ${ }^{44}$. Zaplanowana na szeroką skalę i realizowana już od 1 września 1939 roku przez gauleitera Okręgu Rzeszy Gdańsk-Prusy Zachodnie, Alberta Forstera, akcja germanizacyjna Pomorza spowodowała niepowetowane straty wśród polskiej inteligencji. Rozstrzeliwanie pomorskiego ziemiaństwa, nauczycieli, duchowieństwa, lekarzy i innych przedstawicieli polskiego społeczeństwa, a pozostałych przy życiu umieszczenie w obozach koncentracyjnych lub wysiedlenie w zasadzie pozbawiło naród polski na Pomorzu warstwy kierowniczej ${ }^{45}$.

Ostatnią wigilię w grudniu 1944 roku więźniarki przeżyły w atmosferze zbliżającego się wyzwolenia. Najbardziej tragiczny okres w dziejach KL Stutthof miał jednak dopiero nastąpić. Panująca od listopada 1944 roku epidemia

42 Tamże, s. 77, 91.

43 Tamże, s. 91.

${ }^{4}$ P. Hauser, Mniejszość niemiecka w województwie pomorskim w latach 1920-1930, Wroclaw 1981, s. 39.

${ }^{45}$ D. Schenk, Albert Forster gdański namiestnik Hitlera. Zbrodnie hitlerowskie w Gdańsku i Prusach Zachodnich, tłum. W. Tycner, J. Tycner, Gdańsk 2002, s. 233-275. 
tyfusu oraz rozpoczęta 25 stycznia ewakuacja lądowa więźniów, tak zwany marsz śmierci, a następnie ewakuacja morska, spowodowała utratę życia przez wiele tysięcy więźniów, w tym niektóre więźniarki z tej grupy. Helena Jarocka wspomina ostatnie święta spędzone w obozie:

Ostatnią imprezę urządziłyśmy w wigilię 1944 r. Miałyśmy wtedy wielką swobodę, bo naloty powietrzne sprzymierzonych sił antyhitlerowskich, płoszyły esesmanów, którzy uciekali do bunkrów. We wszystkich izbach urządzano uroczystości. U nas w „trójce” wigilia odbyła się wyjątkowo uroczyście. Zorganizowano ją pod kierownictwem Jadzi Roteckiej i Eli Marcinkowskiej. Podczas części poważnej o nastroju religijnym znajdował się ołtarz tonący w kwiatach zorganizowanych przez Kazię Bartel, której wujek pracował w ogrodnictwie i przy płonących świeczkach. Pomiędzy kwiatami, w pięknie przez Elę Marcinkowską wyhaftowanej i uszytej szkatułce leżały komunikaty, które dotarły do nas przez pralnię, gdzie kapo była Kazia Rogozińska. Przed szkatułką stała szopka. W centralnym miejscu żłobek z dzieciątkiem, wołem i osłem po bokach. Figurki te ulepiła Wanda Sokolińska. Z dwóch stron umieszczono parami figurki lalek ubrane w stroje ludowe wszystkich regionów Polski. Stroje te wykonała Stefa Miotk. Aga Recław rozpoczęła wieczór czytaniem mszału. Helusia Chrzanowska przeczytała kazanie napisane przez księdza Niewiadomego. Chór śpiewał kolędy, a akompaniowała na skrzypcach Stefa Osowska. Stefa zagrała również kolędy solo na skrzypcach. Po części poważnej zasiadłyśmy do wieczerzy. Stół udekorowały siostry Dąbrowskie, Teresa Wilska i Helena Gwiaździna. Do podziału poszły nasze paczki. Na wieczerzy i dalszej imprezie była aufseherka Bothe, wystraszona pochodem zwycięskich wojsk radzieckich i bombardowaniem swego Vaterlandu. Od niej dowiedziała się Jadzia Rotecka, że wszyscy esesmani i Rapportführer są pijani, tak więc nie musiałyśmy się ich obawiać, że do nas przybędą. Po wieczerzy nastąpiła część rozrywkowa - złożyły się na nią tańce, recytacje wierszy i wesołe inscenizacje. Był również gwiazdor z prezentami. Z tańców najbardziej patriotyczny był kujawiak Wieniawskiego. Nazwisk dziewcząt, które go tańczyły, nie pamiętam, pamiętam natomiast jak były ubrane. Jedna z nich miała białą spódniczkę i czerwoną bluzkę, druga zaś odwrotnie, czerwoną spódniczkę i białą bluzkę. Na czerwonym tle bluzki i spódniczki naszyto polskie orły (białe). Poza tym wykonano krakowiaka w cztery pary, trojaka, mazura i oberka. Wszystkie tańce odtańczono w najbardziej autentycznych strojach, które uszyła Dembińska, Celina Ciesielska i kilka więźniarek zatrudnionych we Flickkamerze, gdzie znajdowały się maszyny do szycia ${ }^{46}$.

Pewna ustabilizowana sytuacja w obozie zmieniła się w drugiej połowie 1944 roku. Osadzenie w ciągu pół roku ponad 49 tysięcy więźniów żydowskich, w tym głównie kobiet, spowodowało znaczne pogorszenie warunków sanitarnych w obozie. Był to również rok dużych zmian na frontach, co z kolei

${ }^{46}$ Relacja H. Jarockiej, dz. cyt., t. 18, s. 102-103. 
miało wpływ na łagodniejsze traktowanie więźniów. Helena Jarocka, która złożyła najobszerniejszą relację z KL Stutthof więźniarek osadzonych w obozie w grudniu 1942 roku, opisała również ich pierwsze dni pobytu:

Stutthof zdawał się nam być piekłem dantejskim nie mniejszym niż Gestapo. Niesamowite apele w grudniowe noce - pełne wrzasków, ohydnych przekleństw, strzelaniny, odgłosów uderzeń i kopniaków, jęków więźniów snujących się jak cienie, jak szkielety. Robiło to na nas okropne wrażenie. Spoza zwałów naelektryzowanych drutów kolczastych dochodziła do nas pieśn śpiewana na apelu przez mężczyzn. Niemieckie słowa o pracy, która oswobadza: und es kommt die Zeit und es kommt der Tag, das wir die Freiheit errungen (i nadszedł czas i nadszedł dzień, kiedy osiągnęliśmy wolność) - głosy ochrypłe, zrozpaczone. Nam się wtedy zdawało, że te słowa urągają patrzącym na nieustannie dymiący komin krematoryjny - jedyną drogę do wolności. Dookoła jak okiem sięgnąć widać było druty kolczaste, wśród nich sterczące wieże strażnicze z postenami trzymającymi w łapach gotowe do strzału karabiny maszynowe. Lufy skierowane były w nas.

Inny obrazek z życia obozowego. Jest niedziela. Blokowa prowadziła nas w przedwieczornej godzinie do toalety. Za rewirem i łazienką druty, a za nimi męski obóz. Ujrzałyśmy tam duże koło trzymających się za ręce Rosjan. W środku koła stał esesman z batem, na zewnątrz koła stało również kilku z batami. Ten w środku wydaje komendy (...), a więźniowie musieli galopem biec według komendy i śpiewać smętne rosyjskie pieśni. Zmiana w kroku, nieuwaga na komendę, nie branie udziału w śpiewie - wszystko to karano razami. Spojrzałyśmy w twarze tych biedaków. Tępe lub pełne rozpaczy oczy, niektóre już nic nie widzące, konające. Po takiej zabawie silniejsi z uczestników wynoszą tych, którzy tam skonali lub dogorywali ${ }^{47}$.

Wymieniona grupa polskich więźniarek została umieszczona w baraku w części zwanej starym obozem, która była odizolowana od nowego obozu i obozu żydowskiego. Jedynie pracując w warsztatach obozowych, o czym pisze Helena Jarocka, kobiety miały możliwość zaobserwowania sytuacji panującej w lagrze:

Któregoś dnia Goncarzewicz zabrał mnie do męskiego warsztatu w jakiejś urzędowej sprawie. Poprowadził mnie na tyły warsztatów pod blok Żydówek i powiedział: Przyjrzyj się dobrze i zapamiętaj ten widok. Jeśli nie wrócę do domu, może tobie się uda i wtedy będziesz świadkiem tego, co się tutaj działo. Patrzyłam na to ponure zjawisko z nierzeczywistego świata. Przed blokami snuły się widma, szkielety prawie nagie z obłędem w oczach, z pianą na ustach w gorączce. Jedne z nich ciągnęły z bloku nagie, sczerniałe trupy układając je pod ścianą, inne biegały jak spłoszone zwierzęta tam i z powrotem lub w kółko, wydając przy tym rozpaczliwe jęki. Jeszcze inne zrezygnowane siedziały w kucki, nieczułe na nic. Mietek szeptał: tu nie

47 Tamże, s. 75-76. 
wchodzi żadna aufseherka, żadna pielęgniarka, tu nie przywożą kotłów z jedzeniem, tyle co jakiś mężczyzna potajemnie rzuci przez druty kromkę chleba ${ }^{48}$.

Tutaj też w miarę swoich możliwości udzielały niewielkiej pomocy więźniom żydowskim:

Pod oknami naszych warsztatów codziennie przechodziły robocze komanda Żydów. Nam nie wolno było otwierać okien, a dożywianie Żydów zaliczone było do najcięższych przestępstw. Więźniarki siedzące przy oknach mimo tego zakazu miały za zadanie dożywiać przechodzących więźniów. Oddawałyśmy im chleb, a one sprawnie otwierały okna i rzucały go w szeregi przechodzących więźniów. W naszym warsztacie robiła to: Aga Recław i Rosjanka Lena ${ }^{49}$.

W drugiej połowie 1944 roku w KL Stutthof rozpoczęła się eksterminacja więźniów w komorze gazowej. Metodę tę zastosowano przede wszystkim wobec Żydówek, które też stanowiły największą siłę roboczą dla rozsianych po całym Pomorzu, a także w Prusach Wschodnich podobozów KL Stutthof. Praca, którą tam wykonywały, miała na celu ich eksterminację. W samym obozie Stutthof, ze względu na panujące w nim przeludnienie, nie było dla nich pracy. Tylko niektóre dostały się do kuchni obozowej do obierania ziemniaków czy do pracy w obozowej pralni. W większości przebywały na terenie obozu żydowskiego, odizolowane od innych więźniów, pozostawione same sobie, skazane na powolną śmierć. Również wśród Żydówek największe żniwo zbierała epidemia tyfusu, która wybuchła w obozie w listopadzie 1944 roku i trwała aż do kwietnia 1945 roku. O uratowaniu dwóch Żydówek wspomina Hanna Paszkowska, która w styczniu 1945 roku została zatrudniona jako lekarz w żeńskim rewirze w nowym obozie, który utworzono w czasie panującej epidemii:

Przed samą ewakuacją, gdzieś w kwietniu 1945 roku, wróciliśmy na stary lagier wraz z całym szpitalem na bardzo krótki okres czasu, to już był okres zupełnego rozprzężenia i wtedy ten rewir kobiecy z nowego lagru mieścił się po męskiej stronie, bodajże w pierwszym bloku. (...) W momencie, kiedy przechodziliśmy obozem aryjskim z naszym rewirem - proszono mnie o zabranie dwóch Żydówek. Przyprowadzono je w momencie, kiedy wychodziliśmy o szarówce, włączyliśmy je w stan chorych, przeprowadziliśmy na stary lagier, umieściłam je wysoko na „trzecim piętrze” i one nie wychodziły wcale. Podawało im się jedzenie, nie kręciły się po obozie i szczęśliwie przetrwały i pojechały do Szwecji razem z nami ${ }^{50}$.

\footnotetext{
48 Tamże, s. 98-99.

49 Tamże.

50 Relacja A. Paszkowskiej, dz. cyt., s. 142.
} 
Obóz koncentracyjny Stutthof był także miejscem, gdzie wykonywano na kobietach egzekucje. 5 grudnia 1943 roku wykonano tam wyrok śmierci przez powieszenie na więźniarce Mariannie Dubrackiej. Była to mieszkanka miejscowości Soboklęszcz w powiecie płońskim, została wraz z mężem, Stefanem Dubrackim, aresztowana za „przychylny stosunek do Żydów” uznanych za bandytów. 16 września 1943 roku wobec Marianny Dubrackiej Główny Urząd Bezpieczeństwa Rzeszy (Reichssicherheitshauptamt) zlecił zastosowanie tak zwanego Sonderbehandlung (specjalnego traktowania), co oznaczało wykonanie wyroku śmierci. W zachowanym wpisie do księgi zmarłych USC jako przyczynę zgonu podano: „wurde auf Befehl erhängt” (powieszona na rozkaz) ${ }^{51}$.

Kilka tygodni przed rozpoczętą w styczniu 1945 roku ewakuacją więźniów, 17 grudnia 1944 roku stracono w obozie dziewięć osób, w tym pięć kobiet, rosyjskich jeńców wojennych; były to głównie spadochroniarki ${ }^{52}$.

Zestawienie przekazów polskich więźniarek, które stanowiły odrębną, stosunkowo niedużą i w miarę jednolitą pod względem wykształcenia grupę, zżytą i solidarną, daje nam pełny obraz wydarzeń w KL Stutthof.

\section{Bibliografia}

\section{Źródła}

Archiwum Muzeum Stutthof:

Ksiega ewidencyjna więźniów KL Stutthof, AMS, sygn. I-IIE-12.

Księga ewidencyjna więźniów, sygn. I-IIE-6.

Ksiegga zgonów USC, sygn. Z-V-8.

Ksiega zgonów USC, sygn. Z-V-16.

Lista transportowa więźniów, sygn. I-IIB-12.

Lista transportowa więżiów wywiezionych do KL Tuchingen 28.03.1944 r., sygn. I-IIC-3. Listy transportowe więzniów przestanych przez Sipo Warschau 31.08.1944 r. i 29.09.1944 r., sygn. I-IIB-7.

Wykaz przeniesień na bloku nr I od 14.07.1942 r. do 26.03.1943 r., sygn. I-IIIB-1. Relacje i wspomnienia, t. 6: Relacje E. Marcinkowskiej-Szucy, Cz. Szlachcikowskiego, M. Klosek-Reiter.

Relacje i wspomnienia, t. 9: Relacja H. Jarockiej.

Relacje i wspomnienia, t. 15: Relacje A. Paszkowskiej, C. Ciesielskiej. Relacje i wspomnienia, t. 18: Relacje H. Jarockiej.

51 Księga zgonów USC, AMS, sygn. Z-V-16; D. Drywa, Więźniowie osadzeni w KL Stutthof za pomoc udzielana Żydom, „Zeszyty Muzeum Stutthof” 2017, nr 5, s. 52.

52 M.E. Jezierska, Straceni w obozie Stutthof, „Zeszyty Muzeum Stutthof” 1987, nr 7, s. 137. 


\section{Opracowania}

Danielewicz G., Koprowska M., Walicka M., Polki w Wolnym Mieście Gdańsku, Gdańsk 1985.

Drywa D., Polacy z III grupy DVL osadzeni w KL Stutthof za ucieczki z Wehrmachtu [w:] Pomorzanie w Wehrmachcie. Materiaty z XXI sesji naukowej w Toruniu $w$ dniu 3 listopada 2011 roku, red. J. Sziling, Toruń 2012.

Drywa D., Säuberungsaktion na Pomorzu Gdańskim w świetle dokumentów KL Stutthof (1939-1942), Sztutowo 2014.

Drywa D., Więźniowie osadzeni w KL Stutthof za pomoc udzielana Żydom, „Zeszyty Muzeum Stutthof” 2017, nr 5.

Drywa D., Zagtada Żydów w obozie koncentracyjnym Stutthof(wrzesień 1939-maj 1945), Gdańsk 2001.

Grabowska J., Martyrologia kobiet i dzieci [w:] Stutthof-hitlerowski obóz koncentracyjny, red. D. Steyer, Warszawa 1988.

Hauser P., Mniejszość niemiecka w województwie pomorskim w latach 1920-1930, Wrocław 1981.

Jezierska M. E., Straceni w obozie Stutthof, „Zeszyty Muzeum Stutthof” 1987, nr 7.

Orski M., Niewolnicza praca więźniów obozu koncentracyjnego Stutthof $w$ latach 1939-1945, Gdańsk 1999.

Schenk D., Albert Forster gdański namiestnik Hitlera. Zbrodnie hitlerowskie w Gdańsku i Prusach Zachodnich, tłum. W. Tycner, J. Tycner, Gdańsk 2002.

Zwarra B., Gdańsk 1939. Wspomnienia Polaków-Gdańszczan, Gdańsk 1984. 